\title{
Students' Metacognitive Strategy Pattern in English Academic Writing Learning Using Zoom
}

\author{
Euis Meinawati* 1 , Prapti Wigati Purwaningrum ${ }^{2}$, Herlin Widasiwi \\ Setianingrum3, Sufi Alawiyah4, Lia Nurmalia5, Nurmala Dewi6, Meiva Eka Sri \\ Sulistyawati7, Viviana Lisma Lestari8
}

DOI: $10.35445 /$ alishlah.v13i1. 477

Article Info

Keywords:

Activity's Pattern

Academic Writing

English

Metacognitive Strategy

Zoom

Kata kunci:

Pola Aktivitas

Menulis Akademik

Bahasa Inggris

Strategi Metakognitif

\section{Abstract}

Students have a different pattern in using the learning strategy. It is seen in their activity when they do the writing. The objective of this research was to observe the students' pattern using metacognitive strategy in English Academic Writing learning through an online zoom application. The method used descriptive qualitative research. The data is taken from observation and survey from 20 participants who got the English academic writing subject in 2019/2020 academic years at English Program Study Universitas Bina Sarana Informatika. Analysis procedures include observation of activity patterns, identifying learning strategy patterns, categorizing, and strategy learning pattern analysis. The results showed that the students used metacognitive strategy in the academic writing process with different patterns. It can see from activity steps of the metacognitive strategy that is implemented in the class. Students' activity pattern is planning, identifying, correcting errors, revising, rereading, monitoring, and evaluating. Metacognitive strategies had used by students to consciously control the writing activity because each segment of one's stored world knowledge help students to create the story. The study's implication is managing students' activity patterns when the teacher used the strategy learning. It has to be appropriate to students' needs.

\begin{abstract}
Abstrak
Mahasiswa mempunyai pola yang berbeda dalam mengunakan strategi pembelajaran. Pola tersebut dapat terlihat dari setiap aktivitas ketika membuat tulisan. Tujuan dari penelitian ini adalah untuk mengobservasi pola aktivitas mahasiswa menggunakan strategi metakognitif dalam pembelajaran menulis akademik bahasa Inggris melalui aplikasi zoom. Data diambil dari
\end{abstract}

\footnotetext{
${ }^{1}$ Bahasa Inggris, Universitas Bina Sarana informatika Jakarta, Indonesia

Email: euis.eum@bsi.ac.id

2 Bahasa Inggris, Universitas Bina Sarana informatika Jakarta, Indonesia Email: prapti.pwp@bsi.ac.id

3 Bahasa Inggris, Universitas Bina Sarana informatika Jakarta, Indonesia Email: herlin.hww@bsi.ac.id

4 Bahasa Inggris, Universitas Bina Sarana informatika Jakarta, Indonesia Email: sufi.sfy@bsi.ac.id

5 Bahasa Inggris, Universitas Bina Sarana informatika Jakarta, Indonesia Email: lia.lnm@bsi.ac.id

${ }^{6}$ Bahasa Inggris, Universitas Bina Sarana informatika Jakarta, Indonesia

Email: nurmala.nmd@bsi.ac.id

7 Bahasa Inggris, Universitas Bina Sarana informatika Jakarta, Indonesia

Email: meiva.mes@bsi.ac.id

8 Bahasa Inggris, UIN Syarif Hidayatullah Jakarta

Email: Viviana.lisma@uinjkt.ac.id
} 
observasi dan survei pada 20 partisipan yang mendapatkan mata kuliah menulis akademik tahun ajaran 2019/2020. Prosedur analisis data terdiri dari observasi pola aktivitas, identifikasi pola aktivitas sesuai langkah strategi pembelajaran, mengkategorikan, dan analisis strategi. Hasil analisis menunjukkan bahwa mahasiswa menggunakan strategi metakognitif dalam proses menulis academic dengan pola berbeda. Hal tersebut dapat dilihat dari langkah-langkah aktivitas dari strategi metakognitif yang diimplementasikan di kelas. Pola aktivitas siswa yang teridentifikasi antara lain perencanaan, identifikasi dan koreksi kesalahan, revisi, membaca ulang, monitoring, dan evaluasi. Strategi metakognitif digunakan oleh mahasiswa untuk mengontrol aktivitas menulis karena setiap segmen dalam pengetahuan yang dimiliki membantu mahasiswa untuk menciptakan suatu cerita. Implikasi penelitian adalah pengelolaan pola aktivitas mahasiswa di kelas Ketika pengajar menggunakan strategi pembelajaran. Hal ini bisa disesuaikan dengan kebutuhan mahasiswa.

\section{INTRODUCTION}

English writing has a different challenge in the class. Writing is a difficult activity for some students because it combines linguistic, stylistic, and discourse-related elements to make form and meaningfully functional. They need appropriate strategies to create the segment in writing to be good writing. With the development of cognitive psychology, metacognition has attracted more and more researchers' attention and provided new perspectives for EFL writing. Metacognitive theory mainly includes metacognitive knowledge and metacognitive strategies. Among all learning strategies, metacognitive strategies are high-level executive skills that include planning, monitoring, and evaluation. Once learners have a good command of metacognitive strategies, they will become more independent and autonomous and will be better able to plan, monitor, and evaluate their learning process and become efficient learners. This teaching approach embodies the idea of student-centered teaching and is targeted to foster students' metacognitive strategies, monitor and evaluate the English writing ability(Lv \& Chen, 2010). For students in China, the application of cognitive and metacognitive strategies in English learning positively impacts students' English skills (Liu, 2009).

Rahimi \& Karbalaei (2016) investigated the role of metacognitive strategy in developing writing skills among Iranian EFL students. Written self-regulated strategy instructions are implemented in the classroom (Paris, 2003). Recently, Nemat Tabrizi \& Rajaee (2016) tried to show how cognitive and metacognitive writing strategies can affect elementary-level learners' total writing scores. Metacognitive strategies help students to achieve their desired goals and have better control over their behaviour and learning, which is consistent with the results of this study (Zimmerman \& Schunk, 2011). Therefore, learners in different age groups and contexts use metacognitive strategies to develop their writing performance (Nguyen \& Gu, 2013). It can be confirmed in the investigations of learners in different age groups and contexts (Abdollahzadeh, 2010; Al-Jarrah, Al-Jarrah, Talafhah, \& Bashir, 2019; Panahandeh \& Asl, 2014; Teng, 2016).

Several previous studies have proven that metacognition can also be integrated with teaching English writing (Xiao, 2007). As two writing strategies, cognitive and metacognitive strategies have been extensively researched over the last few decades. Meanwhile, metacognitive strategies also have a positive impact on writing learning. Meta-cognitive strategies increase students' motivation to set their goals and plans through cooperative learning, which helps in improving their academic writing in English (Al-Zubeiry, 2019). There are different interventions in terms of content in implementing cognitive and metacognitive strategies. There was a significant relationship between the cognitive and metacognitive groups. In other words, the metacognitive group outperformed the cognitive group in writing content (Pitenoee, Modaberi, \& Ardestani, 2017; Al-Zubeiry, 2019).

Therefore, the metacognitive strategy has many steps in writing learning. It influenced many factors to build the perception and the appropriate writing strategies. Arndt has categorized the English writing strategies, including planning, global planning, rehearsing, repeating, rereading, 

have found that strategies such as summarizing, reaffirming, and selecting ideas were only evidenced during the post-intervention essay. While Sasaki (2000)used eight writing strategies, these are planning, retrieving, generating ideas, verbalizing, translating, rereading, evaluating, and questioning, but Cer (2019) used the classic and metacognitive strategy-based writing instruction with their expected learning outcome, including; a) Basic Training (Declarative Knowledge (Person Knowledge), b) Declarative Knowledge (Task Knowledge), c) Procedural Knowledge, Conditional Knowledge), d) Expected Learning Outcome (Self-Planning and Drafting, e) Self-Monitoring, SelfEvaluation, and Revision), and f) Expected Quality.

This study focused on the English academic writing activity using zoom with the metacognitive strategy. The conditions of the Covid-19 pandemic require us to carry out online learning activities by utilizing various electronic applications. However, the learning process provides effectiveness on the results of learning to write. Many previous studies have proven this. Technology makes it easy for distance learning or online today. Social media has been used as a learning medium (Vie, 2018; Keengwe \& Georgina, 2012). Another study concluded that five face-to-face oral discussion tasks and five online text-chat tasks influenced the composting process (Jianling, 2018). Besides that, students have a positive attitude in online learning (Rendahl \& Breuch, 2013).

Thus, writing plays an important function in the learning process. The writer makes a difficult meta-cognitive effort by selecting and organizing ideas, then reviewing and adapting them considering the assignment requirements. Previous research revealed a study on metacognitive strategies in English writing learning, either face-to-face or online. This study has similarities with other studies, namely implementing metacognitive strategies in English writing classes. However, this study focuses on observing student activity patterns in implementing metacognitive strategies for English writing classes.

This study examines students' activity patterns towards the metacognitive strategy stages of learning English academic writing conducted online zoom application. The results of this study are expected to impact the development of the lecturers' understanding that each writing learning strategy must be understood through student activity pattern so that the results of implementing these learning strategies can provide new knowledge about student perceptions about application of learning strategy steps. Besides, this research is also a new insight for developing research related to student aspects' learning strategies. Therefore, the formulation of the study is "how is the students' activity in using the metacognitive strategy in English academic writing class?”

\section{METHODS}

The method used descriptive qualitative research. Qualitative research focused on comprehending social phenomena from human participants' perspectives in natural settings (Ary, Jacobs, Sorensen, \& Razavieh, 2010). The data is taken using observation and survey from 20 participants who got the English academic writing subject in 2019/2020 academic years at English Program Study Universitas Bina Saana Informatika Jakarta. The data were analyzed using five classifications of writing strategies proposed by Cer, Larenas, et al., and Sasaki (Cer, 2019; Larenas et al., 2017; Sasaki, 2000) and Arndt (Riazi et al., 2020). The data analysis was taken, including; 1) observe students activity pattern in Academic writing learning. The observation process is carried out during the teaching and learning activities. Researchers pay attention to each student's writing activity one by one. 2) identifying students' activity patterns in doing the academic writing task that reflected the metacognitive strategies during learning using a zoom. At this stage, the researcher recorded academic writing activity patterns from each stage of the metacognitive strategy. Implementation of metacognitive strategy in academic writing learning has some steps which refer to the concepts from Cer, Larenas, et al., and Sasaki. 3) Categorize the steps in metacognitive strategies used by the student during learning using a zoom. The stages of the metacognitive 
strategies used by the students were categorized according to Cer, Larenas et al., Arndt and Sasaki, and 4) analyzing the strategies encountered.

\section{FINDINGS AND DISCUSSION}

The finding displays the metacognitive data strategy that was taken from (Cer, 2019), (Larenas et al., 2017), (Sasaki, 2000), and Arndt (Riazi et al., 2020) during Academic writing class using zoom. Some steps in the process of identifying students' activity in the class are;

1. Observing Students' Activity in Academic Writing

The teacher explained the material related to academic writing using metacognitive strategy and applied the metacognitive strategy stages in an online academic writing class. The process of observing student activity patterns towards implementing metacognitive strategies is reviewed by how many students do writing activities at each stage of the metacognitive strategy. It means that the academic writing process can carry out repeated activities at each stage of the metacognitive strategy.

2. Identifying Students' Activity in Academic Writing

The teacher records each stage used by students during English writing activities. The repetition of each stage in writing through metacognitive strategies is the main data to determine students' writing activity patterns in metacognitive strategies.

3. Categorizing Students' Activity in Academic Writing

Writing activity data are categorized according to the theoretical concepts of Cer, Larenas, et al., Arndt, and Sasaki. Thus, these findings illustrate the stages of metacognitive strategies from which are widely used by students.

4. Analyzing Students' Activity in Academic Writing

The following is the number of writing activities carried out by each student at each stage of learning academic writing using a metacognitive strategy.

\section{Table 1. Number of Students Activities Pattern in Implementation of Metacognitive Strategy}

\begin{tabular}{lllc}
\hline No & Metacognitive Strategy & Expert & $\begin{array}{l}\text { Number of Students } \\
\text { Activities Pattern }\end{array}$ \\
\hline 1 & Planning & $\begin{array}{l}\text { Arndt (Riazi et al., 2020), } \\
\text { Sasaki (2000) }\end{array}$ & 43 \\
2 & $\begin{array}{l}\text { Identifying and correcting } \\
\text { errors }\end{array}$ & Larenas.et.al (2017) & 55 \\
3 & Revising & Larenas.et.al (2017) & 40 \\
4 & Rereading & Larenas.et.al (2017) & 57 \\
5 & Monitoring \& Evaluation & Sasaki (2000), Cer (2019) & 35 \\
\hline
\end{tabular}

Data table 1 shows several student activities in implementing each stage in the metacognitive strategy. In the first stage of planning, it is known that students have made two changes in planning writing topics. When identifying and correcting errors on a written draft, each student does this process 2 or 3 times. Then at the writing revision stage, students made changes 2 times. Revised writing. Reread it carefully for errors. Students do this activity 2 or 3 times. The final step is monitoring or evaluating to determine the reciprocal process of writing that friends or lecturers have corrected. Students do this activity 1 or 2 times. Therefore, the students had metacognitive behaviors in academic writing in English, namely planning, identifying and correcting errors, revising, rereading, monitoring and evaluation. Metacognitive strategies are defined as strategies used by 
authors to control the writing process consciously. It is caused that metacognitive knowledge is a segment of one's stored world knowledge.

The metacognitive strategy is a special case of cognitive strategy, distinguished by its conscious and active application to control a process when monitoring has indicated that some modification, correction, or resolution must occur for the task to proceed successfully to goal completion. Metacognitive strategies in writing learning can improve writing performance and increase their satisfaction. Students showed a significant improvement in their writing skills (Goctu, 2017). Mistar, Zuhairi, \& Parlindungan (2014) stated that metacognitive and cognitive strategies have an essential role in writing learning. Therefore, lecturers can pay attention to these strategies because they can help students improve their writing. Researchers assume that the strategies (metacognitive, cognitive, and social) are appropriate for learners. Every strategy is related to another strategy. Strategies are based on the stages of the writing process (planning, implementation, and revision), presented in three model factors (cognitive, metacognitive, and social strategies) (Junianti, Pratolo, \& Tri Wulandari, 2020).

There is probably associate inverse relation between bound sorts of metacognitive activity and improved proficiency. Suppose metacognition occurs when other cognitive processes fail, like writing that he or she didn't select the appropriate steps of the writing process or didn't perceive the supply text. In that case, a metacognitive strategy is also activated to rectify matters. From the researcher's point of view, it can be judged that an important aspect of the intervention is to learn together from others. Students can get feedback from lecturers and peers when expressing their thoughts and ideas, which in turn creates the scope for further improvement. Besides, this intervention supports EFL students in becoming familiar with academic writing strategies, increasing self-confidence, enjoying and being comfortable learning writing skills, and overcoming all related problems (Dülger, 2011; Al-Zubeiry, 2019). The uniqueness of this concept has made this research different from others. Expression of students' ideas and thoughts during writing becomes an activity pattern that reflects the application of these learning strategies.

The implication of this study is the activity pattern of students applying metacognitive strategies in developing English academic writing and zooming into a suitable medium for online learning. In the context of research about the writing processes of university students, the teacher can use this strategy to identify the extent to which the students, mainly those who have just started university in their first year, acknowledge their knowledge and strategies for writing.

Thus, metacognitive strategy refers to students' global skills and knowledge of cognition to help them increase self-awareness, direct their learning, and monitor their progress. From the results of this study, there are deficiencies in the reliability test that does not involve peer assessment in academic writing classes. This is due to the learning process carried out through zoom. Peer assessment can provide an in-depth analysis concept in observing student activity patterns. Therefore, further research can focus on engaging peers in the classroom observation process during testing learning strategies and exploring student perceptions of the various aspects of metacognitive strategies.

\section{CONCLUSION}

Students have used planning, identifying and correcting errors, revising, monitoring, and evaluating the metacognitive strategy. The metacognitive strategy is a particular case of cognitive strategy, distinguished by its conscious and active application to control a process when monitoring has indicated that some modification, correction, or resolution must occur for the task to proceed successfully to goal completion. During the writing process, the students showed positive activity patterns for each activity by applying metacognitive strategies. It reflects that students have had engagement during the planning process, writing drafts, editing, and revision. Besides, the results of this study provide a new concept in assessing student activity patterns towards the strategies used by teachers in the classroom. For the teacher, this study can use as a guide to implement learning 
strategies related to the students' needs and develop learning activities to achieve goals. Meanwhile, research is limited to the implementation of metacognitive strategies that are focused on student activity patterns. Even though this strategy is closely related to the personality type of students. Therefore, this research can still be developed concerning students' personality types in shaping writing activity patterns through metacognitive and cognitive strategies.

\section{REFERENCES}

Abdollahzadeh, E. (2010). Undergraduate Iranian EFL Learners' Use of Writing Strategies. Writing \& Pedagogy, 2(1), 65-90. https://doi.org/10.1558/wap.v2i1.65

Al-Jarrah, T. M., Al-Jarrah, J. M., Talafhah, R. H., \& Bashir, I. (2019). Exploring the effect of metacognitive strategies on writing performance. Global Journal of Foreign Language Teaching, 9(1), 33-50. https://doi.org/10.18844/gjflt.v9i1.3977

Al-Zubeiry, H. Y. A. (2019). The Efficacy of Meta-Cognitive Strategies Instruction in Enhancing Saudi EFL Students' Academic Writing. International Journal of Social Sciences \& Educational Studies, 5(4). https://doi.org/10.23918/ijsses.v5i4p71

Ary, D., Jacobs, L. C., Sorensen, C., \& Razavieh, A. (2010). Introduction to Research in Education (8 Edition). CA: Cengage Learning.

Cer, E. (2019). The Instruction of Writing Strategies: The Effect of the Metacognitive Strategy on the Writing Skills of Pupils in Secondary Education. SAGE Open, 9(2), 215824401984268. https://doi.org/10.1177/2158244019842681

Dülger, O. (2011). Meta-cognitive strategies in developing EFL writing skills. Contemporary Online Language Education Journal, 1(2), 82-100.

Goctu, R. (2017). Metacognitive Strategies in Academic Writing. Journal of Education in Black Sea Region, 2(2).

Jianling, L. (2018). The impact of face-to-face oral discussion and online text-chat on L2 Chinese writing. Journal of Second Language Writing, 41, 27-40. https://doi.org/10.1016/J.JSLW.2018.06.005

Junianti, R., Pratolo, B. W., \& Tri Wulandari, A. (2020). The Strategies of Learning Writing Used by EFL Learners at a Higher Education Institution. Ethical Lingua: Journal of Language Teaching and Literature, 7(1), 64-73. https://doi.org/10.30605/25409190.131

Keengwe, J., \& Georgina, D. (2012). The digital course training workshop for online learning and teaching. Education and Information Technologies, 17(4), 365-379. https://doi.org/10.1007/s10639-011-9164-x

Larenas, C. D., Leiva, L. R., \& Navarrete, M. O. (2017). Rhetorical, Metacognitive, and Cognitive Strategies in Teacher Candidates' Essay Writing. PROFILE Issues in Teachers' Professional Development, 19(2), 87-100. https://doi.org/10.15446/profile.v19n2.60231

Liu, M. (2009). An Investigation Of Cognitive And Metacognitive Strategy Use: Changes And Differences. Indonesian Journal of English Language Teaching, 5(2), 6-27. https://doi.org/10.25170/ijelt.v5i2.157

Lv, F., \& Chen, H. (2010). A Study of Metacognitive-Strategies-Based Writing Instruction for Vocational College Students. English Language Teaching, 3(3), p136. https://doi.org/10.5539/elt.v3n3p136

Mistar, J., Zuhairi, A., \& Parlindungan, F. (2014). Strategies of Learning English Writing Skill by Indonesian Senior High School Students. Arab World English Journal, 5(1). Retrieved from https://www.awej.org/index.php/volume-5-2014/46-2014-03-20-02-17-45/440-junaidimistar-alfan-zuhairi-firman-parlindungan

Nemat Tabrizi, A. R., \& Rajaee, M. (2016). The Effect of Metacognitive and Cognitive Writing Strategies on Iranian Elementary Learners' Writing Achievement. International Journal of Learning and Development, 6(3). https://doi.org/10.5296/ijld.v6i3.9935

Nguyen, L. T. C., \& Gu, Y. (2013). Strategy-based instruction: A learner-focused approach to developing learner autonomy. Language Teaching Research, 17(1), 9-30. https://doi.org/10.1177/1362168812457528

Panahandeh, E., \& Asl, S. E. (2014). The Effect of Planning and Monitoring as Metacognitive Strategies on Iranian EFL Learners' Argumentative Writing Accuracy. Procedia - Social and Behavioral Sciences, 98, 1409-1416. https://doi.org/10.1016/J.SBSPRO.2014.03.559

Paris, A. A. (2003). Cognitive writing strategies. Disability and Equity in Education Commons, 1(2), 

$115-128$.

Pitenoee, M. R., Modaberi, A., \& Ardestani, E. M. (2017). The Effect of Cognitive and Metacognitive Writing Strategies on Content of the Iranian Intermediate EFL Learners' Writing. Journal of Language Teaching and Research, 8(3), 594. https://doi.org/10.17507/jltr.0803.19

Rahimi, F., \& Karbalaei, A. (2016). The Role of Metacognitive Strategies Training on Developing Writing Skill among Iranian EFL learners. Journal of Current Research in Science, 1, 327-341.

Rendahl, M., \& Breuch, L.-A. K. (2013). Toward a Complexity of Online Learning: Learners in Online First-Year Writing. Computers and Composition, 30(4), 297-314. https://doi.org/10.1016/J.COMPCOM.2013.10.002

Riazi, A. M., Shi, L., \& Barkaoui, K. (2020). Studies and Essays on Learning, Teaching and Assessing L2 Writing in Honour of Alister Cumming. UK: Cambridge Scholars Publishing.

Sasaki, M. (2000). Toward an Empirical Model of EFL Writing Processes: An Exploratory Study. Journal of Second Language Writing, 9(3), 259-291. https://doi.org/10.1016/S10603743(00)00028-X

Teng, F. (2016). Immediate and delayed effects of embedded metacognitive instruction on Chinese EFL students' English writing and regulation of cognition. Thinking Skills and Creativity, 22, 289-302. https://doi.org/10.1016/j.tsc.2016.06.005

Vie, S. (2018). Effective Social Media Use in Online Writing Classes through Universal Design for Learning (UDL) Principles. Computers and Composition, 49, 61-70. https://doi.org/10.1016/j.compcom.2018.05.005

Xiao, Y. (2007). Applying metacognition in EFL writing instruction in China. Reflections on English Language Teaching (Vol. 6).

Zimmerman, B., \& Schunk, D. H. (2011). Handbook of self-regulation of learning and performance. New York: Routledge. 